\title{
Registration and Georeferencing of the Family Farming Production Chain in Itapúa Department, Paraguay
}

\author{
Hector T. Roos ${ }^{1}$, Fabio S. Pires ${ }^{1}$, Enio Giotto ${ }^{1}$, Bruna D. Pimenta ${ }^{1} \&$ Enrique O. H. Villalba ${ }^{1}$ \\ ${ }^{1}$ Federal University of Santa Maria, Santa Maria, RS, Brazil \\ Correspondence: Hector T. Roos, Precision Agriculture Postgraduate Program, Federal University of Santa \\ Maria, Av. Roraima, n¹000-Camobi, 97105-900, Santa Maria, RS, Brazil. E-mail: hectorthiele@hotmail.com
}

Received: November 19, 2018

Accepted: February 13, 2019 Online Published: April 15, 2019

doi:10.5539/jas.v11n5p161

URL: https://doi.org/10.5539/jas.v11n5p161

\begin{abstract}
This work aimed to develop two computerized systems, modeled to record and provide information about family farming activities within Itapúa Department-Paraguay. Meetings were held with Government members and municipal technicians to obtain all the requirements and to gather all the details that are relevant for the development of the application. Thus, with all the available information, it was possible to organize and structure the two proposed systems to collect data on rural producers, their properties, their production, family composition, livestock production, processed products, infrastructure, input use, etc. As a result an application for Android called C7-SustenLAF and a Web system was developed, where the main application's function is to carry out the data registration of the rural producers, thus providing georeferenced data, in turn the Web system has the purpose of generating and structuring the information as well as enable data retrieval by giving a series of filter options for different characteristics that are registered from the application. Thus, it is expected that these systems, used specifically to give information, can help the Government of Itapúa - Paraguay to take strategic actions and give support to the Family Farming field, contributing to better management and technical assistance to producers.
\end{abstract}

Keywords: family farming activities, applications, C7-SustenLAF, web system, strategic actions

\section{Introduction}

The United Nations (UN) defined 2014 as the International Year of Family Farming (FF). The aim of this action was to increase the visibility of small-scale family farms by drawing the world's attention to its important role in the fight against hunger and poverty, food security, and nutrition, as well as in the improvement of quality of life and natural resources, environmental protection, and the achievement of sustainable development, especially in rural areas.

According to the Paraguay Agricultural Census (CAN, 2009), the primary sector (agriculture, livestock, forestry, hunting and fishing) employs $26.9 \%$ of the economically active population (EAP), which represents approximately 785,000 people, who produce 11 out of the 19 consumables considered (58\%), both for domestic consumption and for export. However, the medium or small size family farming units ( $0-20$ hectares) had the greatest decrease at national level, reaching $71 \%$. This situation is justified by a large expansion of soybean production in this region in recent years. The main causes for the reduction in the small size family farms are low profitability due to lack of qualified technical assistance, degradation of natural resources, and lack of traceability when using economic resources.

Family Farming includes all family-based agricultural activities and is related to various areas of rural development, such as agricultural production, forestry, fishing, pastoral, and aquaculture production. It is operated by a family and depends mainly on family labor, including both men and women (Villalba, 2017).

Precision agriculture is a term related to the precise management of small units of land in contrast to the traditional way, in which an entire field area is uniformly treated, and all operations are performed using an average. Many researchers opt for the size of the settlement area as a central criterion for distinguishing family farming and agribusiness. In Paraguay, a rural producer belonging to the Family Farming production chain cannot exceed 50 hectares of production area, regardless of land use, which includes agricultural activities, livestock, aquaculture, among others (CAN, 2009). 
Family Farming, given its characteristics, is the main source of workforce and manpower of the agricultural sector and the rural space of many countries in Latin America. The study by Salcedo and Guzmán (2014) indicates that the number of family farms in Latin America is 20.4 million. It is estimated that around 60 million people live on them. According to CAN (2009), there are approximately 265,415 rural producers with up to 50 hectares of productive area in Paraguay.

Over the last years, technological development in the agricultural sector has helped the management of several different tasks carried out in a production cycle, both at the farming operations level and processing, organization, search and disclosure of the information. That justifies the constant use of technological tools, which expedite and assist these processes. Thus, any system that manipulates data and provides information, whether it uses information technology resources or not, can be considered, in general terms, an information system.

Thus, the objective of this work was to investigate, within the Itapúa Department Government, the weaknesses of the current Family Farming registration system, enabling the development of computerized systems for proper registration, assisting in new developments, management, access to information and strategic and political action. Among the main characteristics of the system, it was necessary to identify the weaknesses of the current Family Farming registration system, and then develop an application capable of registering the Family Farming data and a Web platform to view the registered information, taking into account the need for georeferencing all the rural producers according to their respective farms.

\section{Materials and Methods}

The project developed is used in Paraguay, specifically in the Itapúa Department, which is located in the southwest of the country's eastern region. This Department is composed of 30 districts (Figure 1). Its capital is Encarnación, and according to the latest Population Census, carried out in 2017, the Department has approximately 592,000 inhabitants.

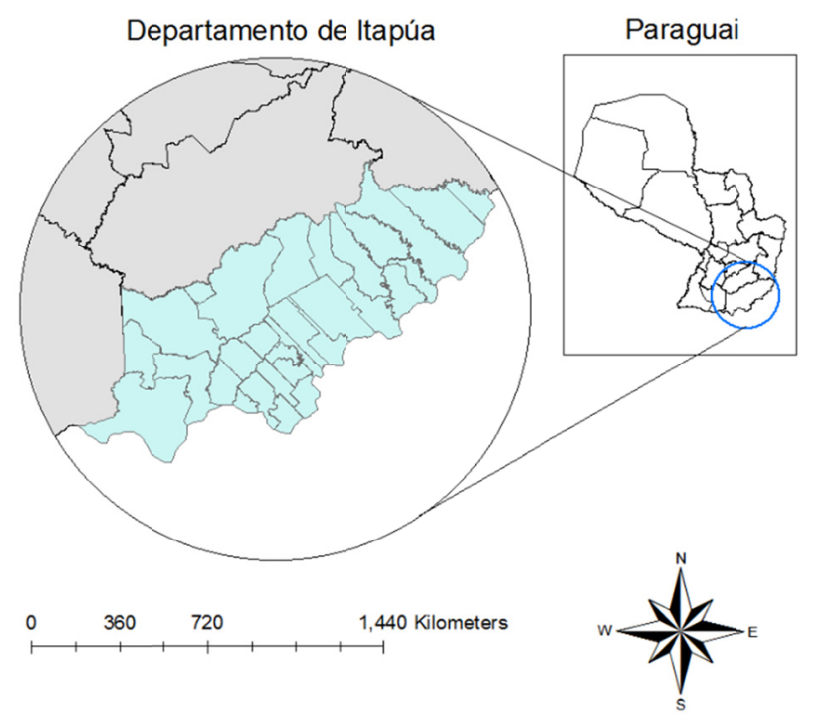

Figure 1. Location area of the system development and use

\subsection{Data Collection and Retrieval of Variables}

A number of meetings, presentations, discussions, and debates were necessary for the development of the system, so that it could encompass, in general, all the requirements of the Itapúa Department Government. The system is based on a document for registering family farmers called RENAF: 'Registro Nacional de Agricultura Familiar' (National Registry of Family Agriculture, in English).

Within the web system, some views that could present an overview of the information collected through the application were defined. This web application was developed using the Ruby on Rails language.

The Android application developed was named C7 Sustenlaf, whose main characteristic is to collect data from the system. It can store this internally collected information on a database of the device itself and also transmit 
that information through the server. It was programmed using the Java language in the Android Studio Software, creating an application for Android devices only.

C7 SustenLAF is the first application based on the CR Campeiro system, which was made available in Spanish Language, since the source of its users is in Paraguay, a neighboring country of Brazil.

\subsection{Data Processing and Analysis}

After identifying the needs, a diagram of entities and relationships was created, which helped in the database development, as well as in the analysis of how the different reports requested could be generated.

In this process, it was possible to identify which variables were essential in the system, in addition to technical requirements such as the need for an off-line application, which allows data synchronization whenever the user wishes so. The variables that should appear as filters options to search information in the Web system were identified too. Another relevant feature is the manipulation of different levels of access in the Web system.

\section{Results and Discussion}

\subsection{C7 SustenLAF Application}

The entire software was developed in Spanish language, as the source of its use and application is in Paraguay. The C7 Susten LAF Application is not publicly distributed because the product has been purchased by the Itapúa Department Government. The application needs to be purchased by the municipality where it will be used by the technician.

After the application is installed, an icon is created, which will allow users to start the tool. Figure 2 shows the icon used to launch the application on a smartphone, as well as the application welcome screen.

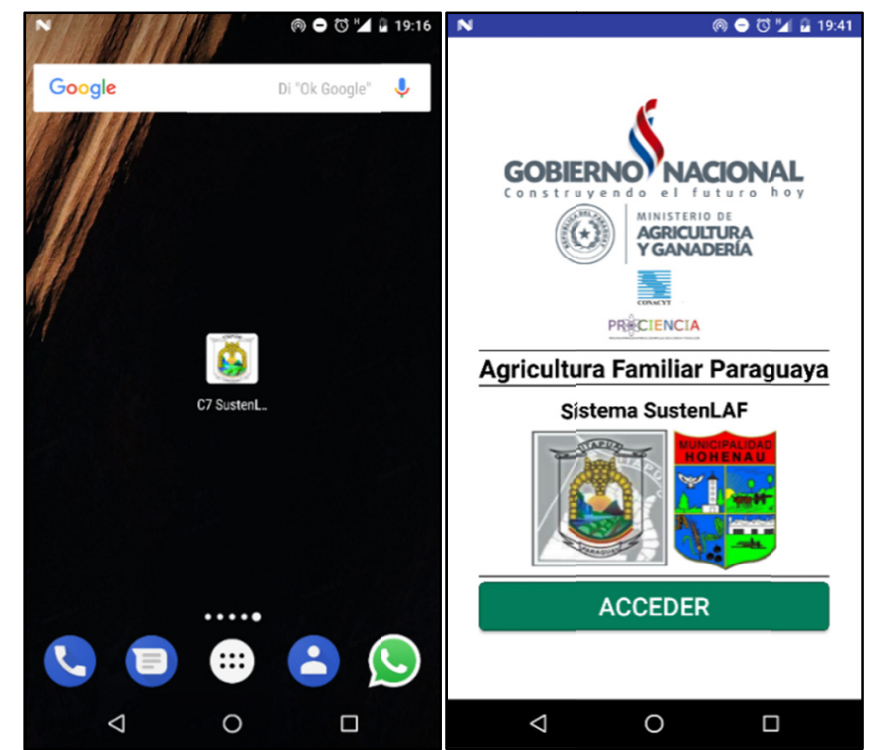

Figure 2. Application launcher icon and welcome screen

To access the main menu, the user must press 'Acceder' (Access, in English), which will lead to the screen with a list of the different application sections (Figure 3). 


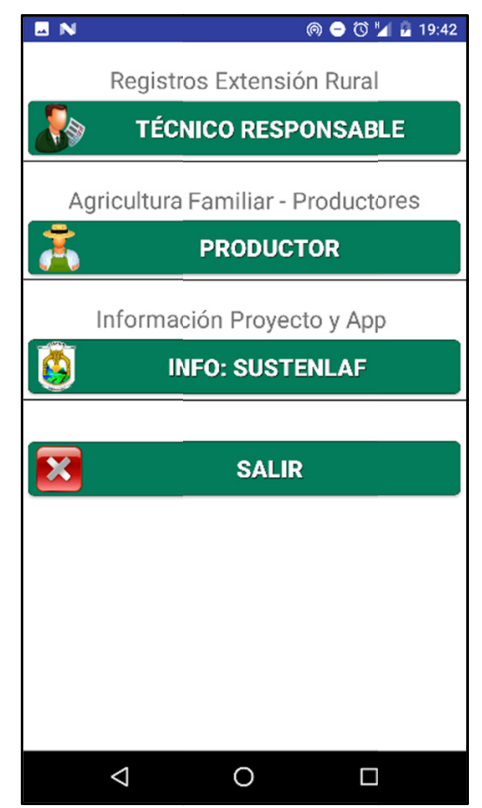

Figure 3. Application Sections

In the screen above (Figure 3), there are the buttons for accessing the following sections:

'Técnico Responsible' (Technical Manager, in English): Section for registering and identifying the application user (registration of producers' information), as well as the scheduling of activities and the real-time transmission of the user's location.

'Productor' (Producer, in English): It gives access to the menu to register different information on producers, according to the analysis of the requirements identified previously.

In Figure 4, one can view all the options for registering data on producers. It is important to mention here that all information manipulated in the different screens accessed from this menu belong to the producer who is also selected on the screen (in a red frame).

\begin{tabular}{|c|c|c|}
\hline 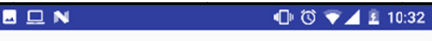 & 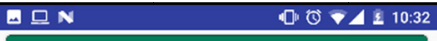 & $40>4 \& 10: 32$ \\
\hline PRODUCTOR & USO DE LA TIERRA & ASISTENCIA TÉCNICA \\
\hline Técnico Responsable & AS TRABAJADORES CONTRATADOS & ASISTENCIA CREDITICIA \\
\hline Hector Thiele/3616264 & CULTIVOS AGRÍCOLAS & INGRESOS Y EGRESOS \\
\hline Juan Chamorro & PRODUCCIÓN GANADERA & INCIDENCIA FACTORES CLIMÁTICOS \\
\hline DATOS DE LA FINCA & Th ELABORACIÓN DE PRODUCTOS & 69 ORGANIZACIÓN DEL PHODUCTOR/A \\
\hline REGISTRO PARCELAS & IMPLEMENTOS & $<$ INFORMACIÓN AGROPECUARIA \\
\hline REGISTRO ESPACIAL & SERVICIOS BÁSICOS & Ne OTRAS PRODUCCIONES Y OBS. \\
\hline LOCALIZACIÓN DE FINCAS & UTILIZACIÓN DE INSUMOS & FOTOGRAFIAS \\
\hline COMPOSICIÓN FAMILIAR & ASISTENCIA TÉCNICA & INFORMES \\
\hline TENENCIA DE LA TIERRA & ASISTENCIA CREDITICIA & ENVIAR LOS DATOS \\
\hline USO DE LA TIERRA & INGRESOS Y EGRESOS & SALIR \\
\hline$\square$ & 0 & 0 \\
\hline
\end{tabular}

Figure 4. Menus of the producer section 
The application then allows the registration of personal data of all producers, as well as that of their spouse (if any). Subsequently, the farms where the producer lives can be registered. It is also possible to register each field within the farm. Both farms and fields can be georeferenced by finding the geographic coordinates from polygon vertices in the 'Registro Espacial' (Spatial Register, in English) menu.

In Figure 5, one can observe which data are registered regarding the producer's farms.
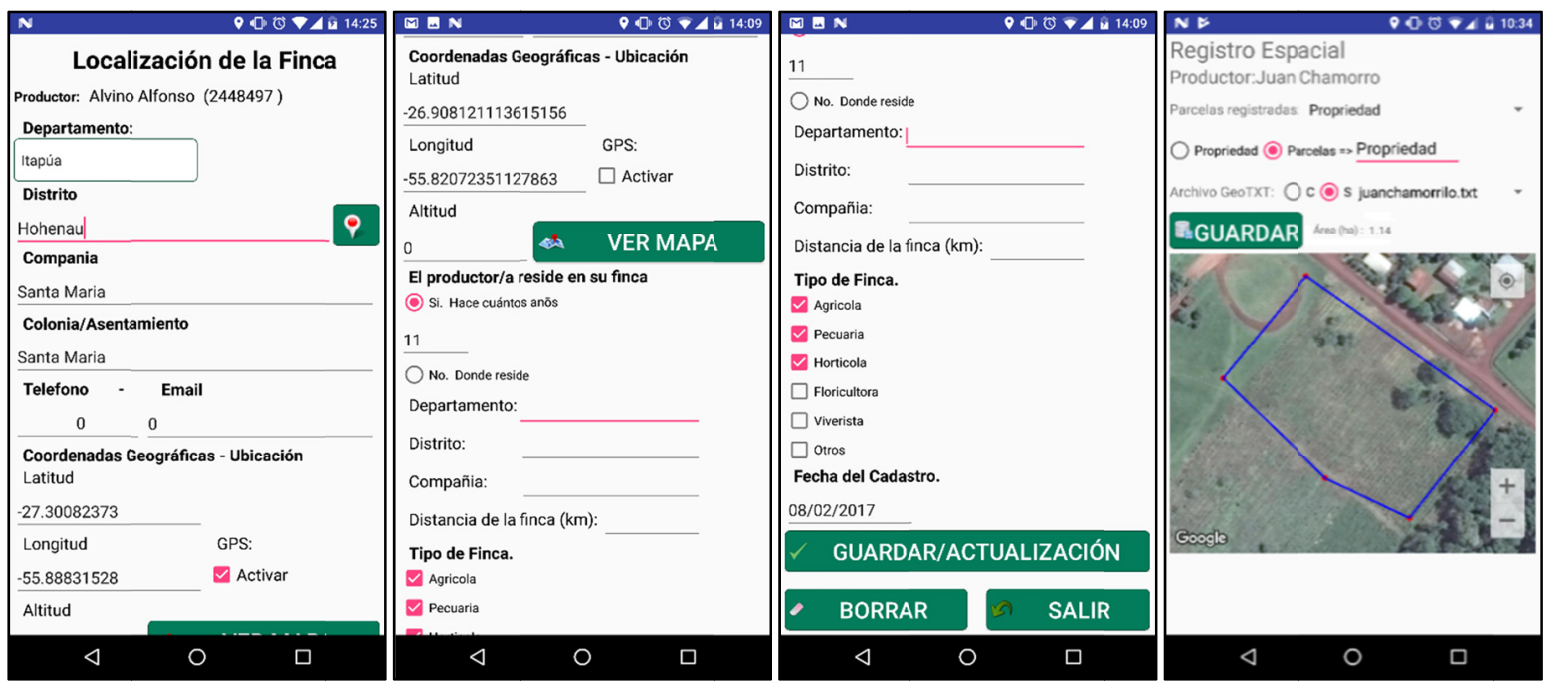

Figure 5. Farms Registration

In order to carry out a census of all people linked to family farming, the application also registers the family members of each producer. Another interesting fact is the registration of the field use by the producer. The goal is to identify the main sources of income in this sector.

Regarding the detailed registration of crops produced by a farmer, information on crop types, current average yield, method of planting, production destination, production income, as well as expenditures on the same production, are included. Likewise, a survey of livestock production data, items produced and processed for sale, such as milk, meat, eggs, flour, and others, is carried out. In this case, the product, volume produced, consumed and marketed, and the income obtained are individually recorded.

Information on the implements and all the infrastructure available to each producer is also recorded. Thus, one can be aware of the producers who has had good results in their production. Information on the availability of utilities such as electricity and drinking water to the producer is also recorded. In addition, details of the public and private entities providing technical assistance to rural producers, as well as financial institutions that provide financial assistance are also recorded. Through the application, any weather incidents that may affect the production of crops and/or products by the producer can be registered too.

The application registers photographs, relating them to different topics, according to the captured image. In addition, a number of reports can be prepared and sent by electronic mail or other means of transmitting documents.

All registered data is stored locally. The user has to be nominated to be able to send all registered data. The nomination is also required to download new data from the application.

\subsection{WEB System}

To advertise the project as a strategy to help producers of the Family Farming production chain, a page was developed with the concepts and information about the project. The web page is composed of 3 (three) core sections: Home or main page, which tells a little about the project; 'El Proyecto' (The Project, in English), which provides more information regarding what the project consists of; and the 'Contacto' (Contact, in English) page, which informs telephone numbers and a short form for sending e-mails. 
As the registered information is not directly published, there is a Login system on the web app, which protects it from public disclosure. Therefore, when a user tries to access protected information, the Login screen will appear, and they must enter their email or username and password.

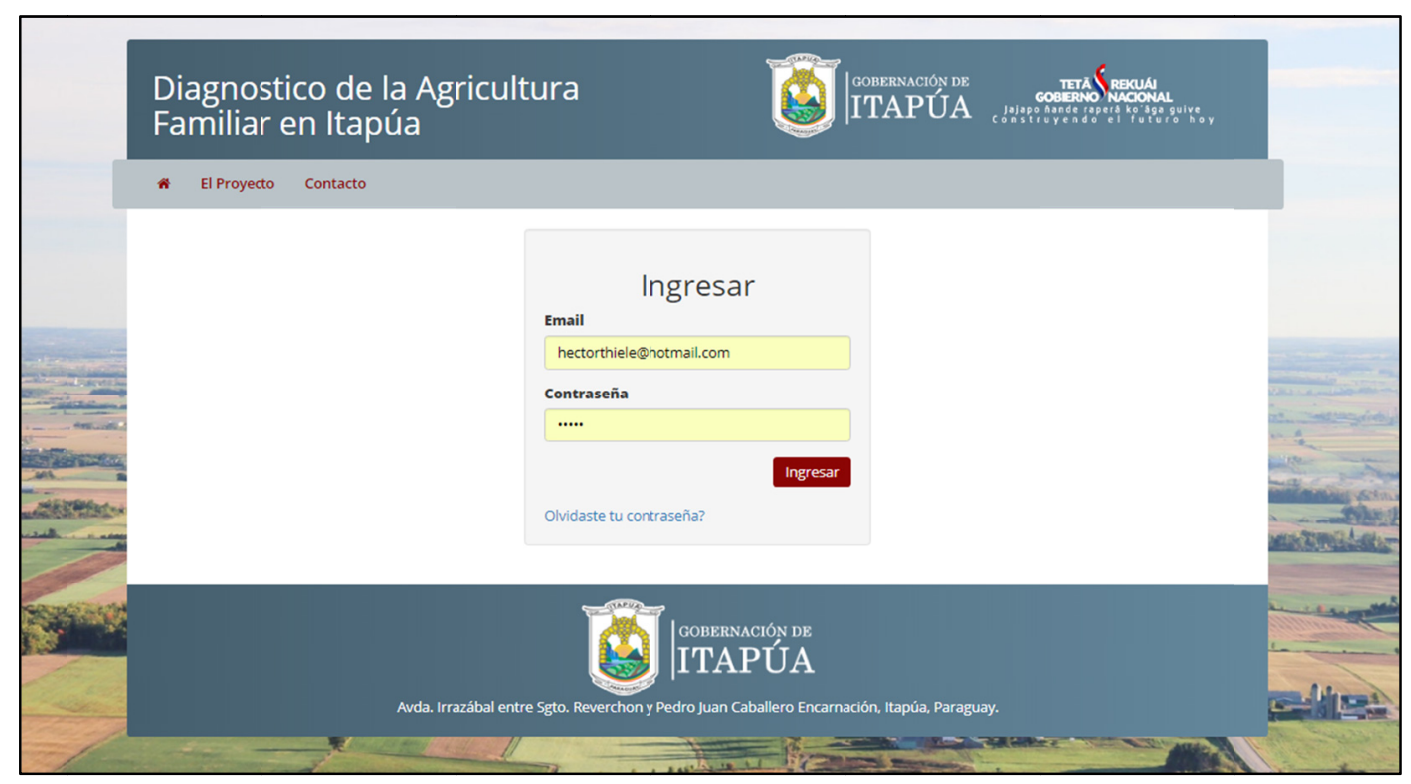

Figure 6. Web application login area

When the user enters their credentials, they can access the module that contains all the information registered through the Android application.

The information registered and viewed on the web system also have their levels of restricted access:

Public Level: Allows user to view the Main page or Home, the page about the project, and the contact page.

Municipality level: Allows the view of information registered only by users who belong to the same municipality as the logged user. That is, if a user joining the system belongs to the municipality of 'Hohenau', they can see only information about producers from their own municipality, and not from others.

Administrator Level: It is the highest level of permission of the system, which allows the logged user to register technicians and new users and also allows to view information on all the producers registered in the system. Administrators can register new web system users.

If the logged user has a so called 'administrator' role, they can view and register technicians in the system. Therefore, the administrator will provide the credentials to the technician so that the latter can then register producers and send the information to the web server. 


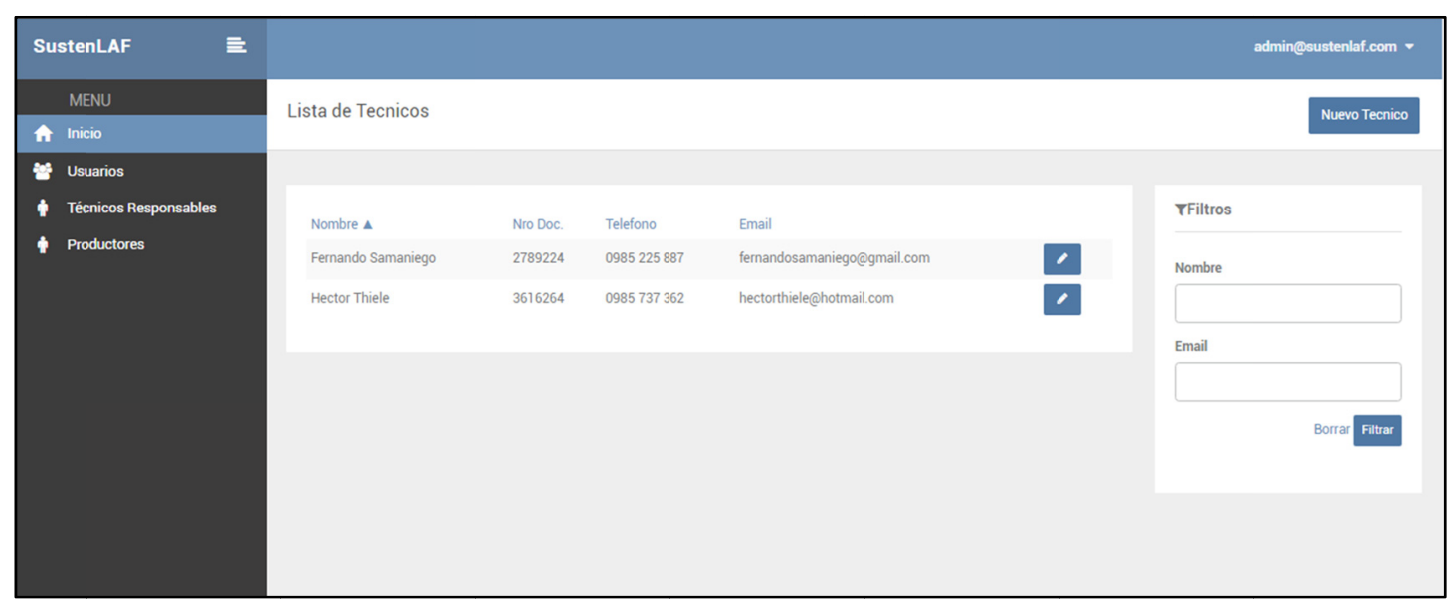

Figure 7. List of technicians registered

The main goal of the web system is to be enable the producers' information registered through the application to be viewed. In the screen where all producers are listed, there are also a list of filters that make it possible to search and retrieve general information instantly.

On the screen, there is also a number of filters that can provide general information, based on queries such as the producers belonging to a certain committee or a certain state, or even producers who grow a certain crop, such as cassava, corn, among others.

Therefore, the web system provides information quickly, making it easier to take action based on variables of the user's interest, which may be at municipal or general level.

Figure 8 shows how producers are listed, and how some basic contact and identification information is shown.

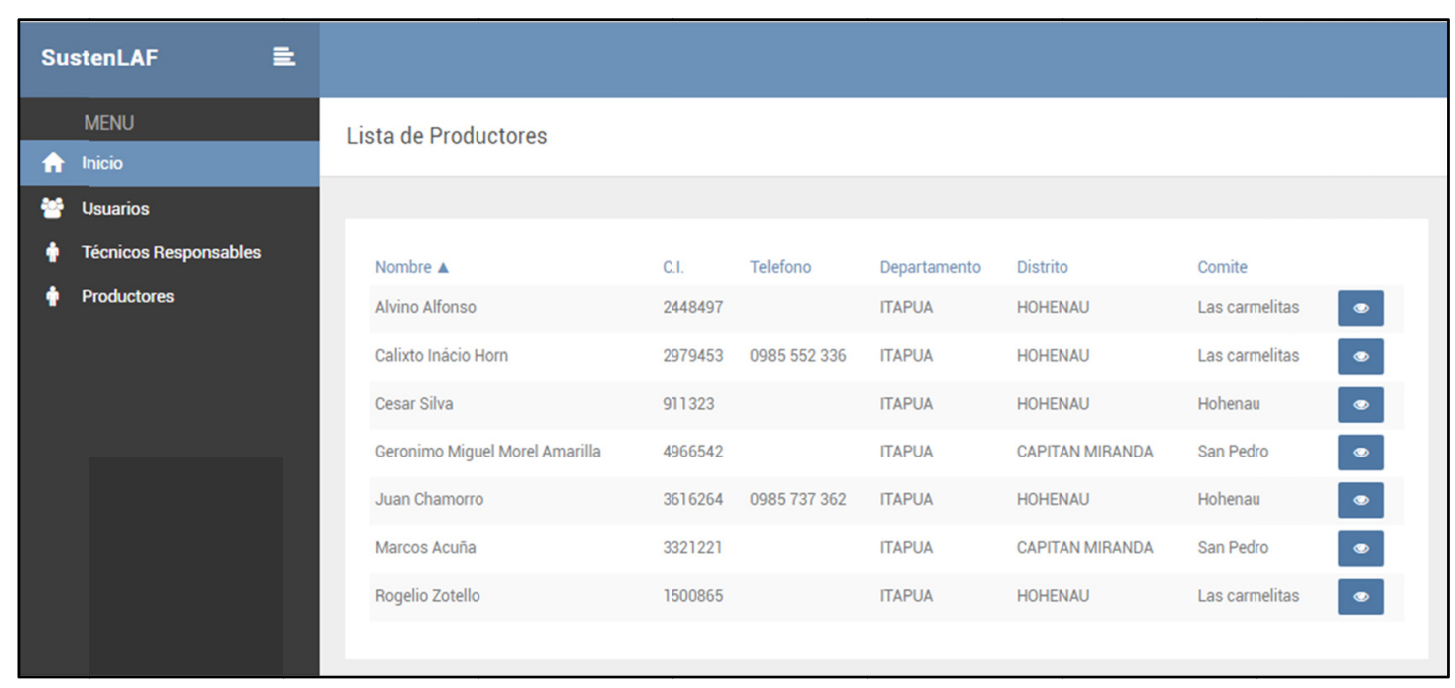

Figure 8. List of producers

On a click, each of the items of the list displayed, such as 'Nombre' (Name, in English), 'C.I.' (ID number, in English), 'Telefono' (Phone number, in English), etc., makes an Ajax call to the server, which allows data to be ordered according to the selected column. By default, they are alphabetically ascending from the 'Nombre' field.

On the right side of the list of producers, there is a number of filters which may be applied to producers (Figure 9). These filters are currently the most relevant to users, such as: what state or Department they belong to, which district, which committee, what type of farm, which crops they produce, among others. 


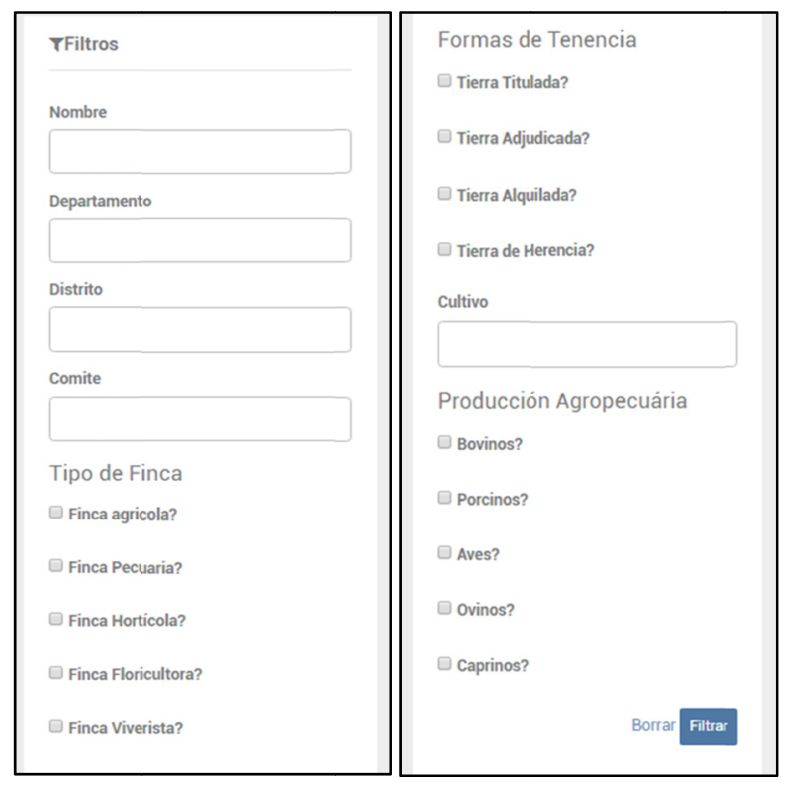

Figure 9. Producers filter

The filters are combined, and more than one for different characteristics, can be used at a time. This provides the user with thorough information that can help taking action regarding a particular situation.

When the producers filter is used by combining any of the filters available in this section, a map with the location of the producers on the list automatically appears. Figure 10 shows how the map is presented, with the location of the producers.

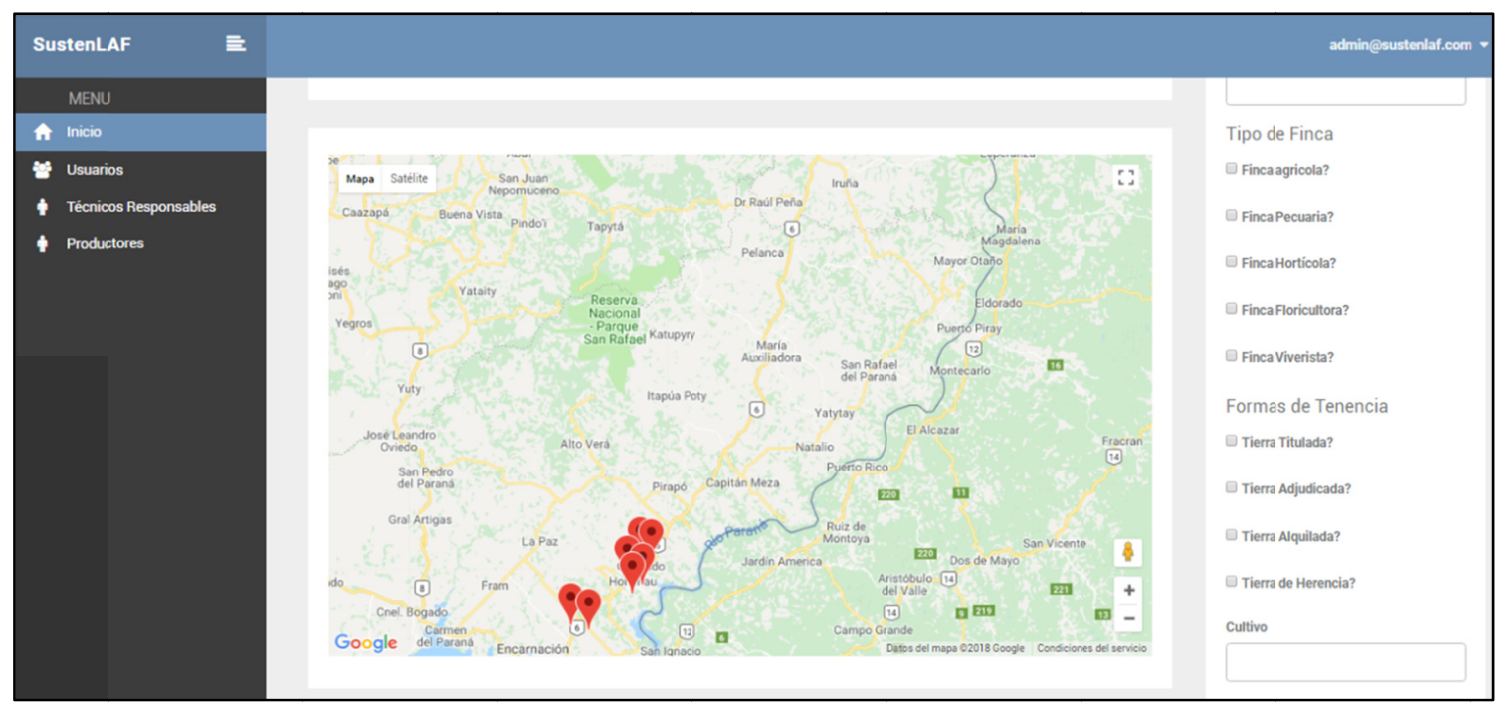

Figure 10. Map with location of searched producers

It is also worth noting that each item of the list has an icon at the end of the line, which is a link to all the selected producer's information, previously recorded through the Android application. Figure 11 shows the registered information of the producer soon after accessing the details window. 


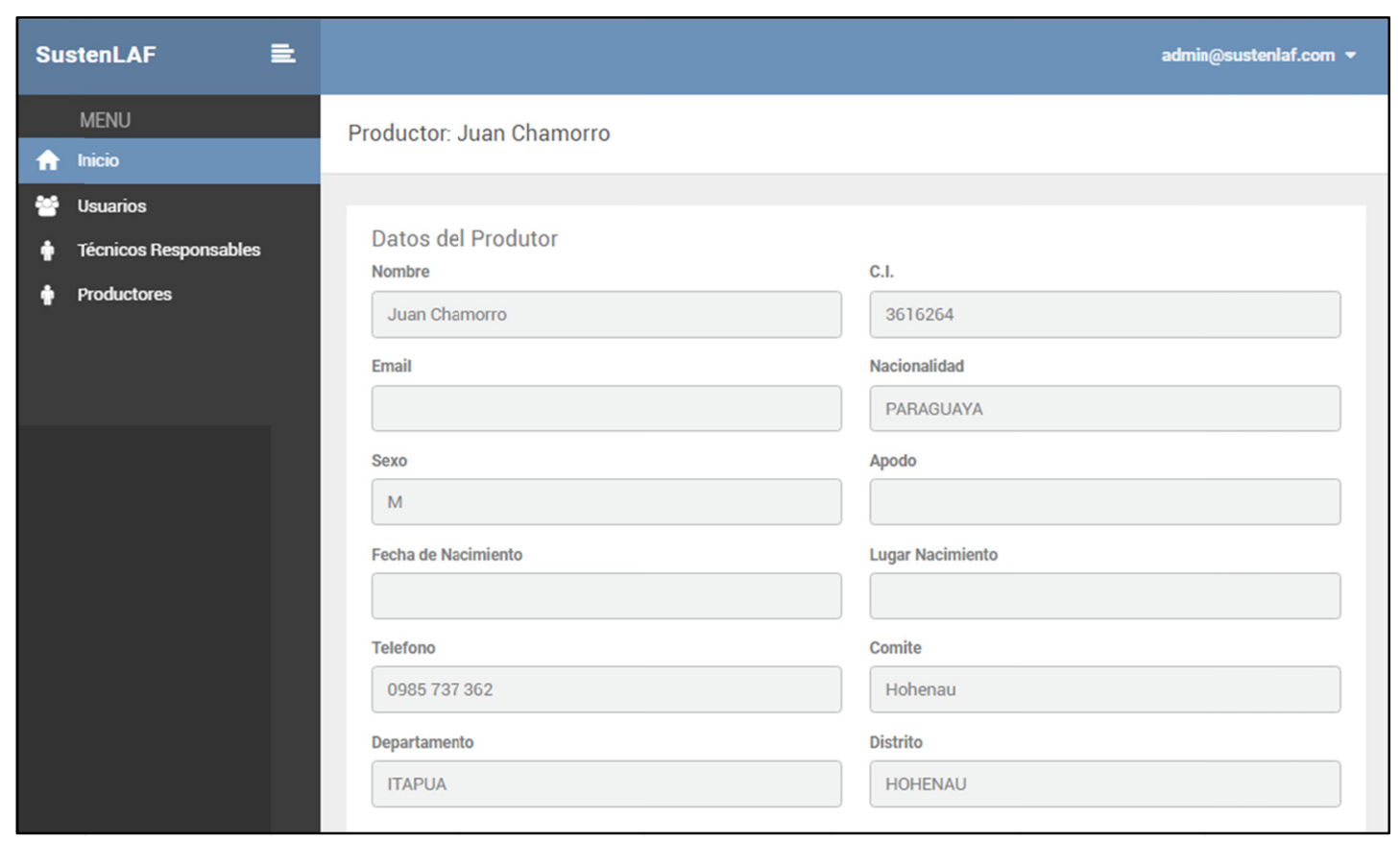

Figure 11. Registered information of the producer

This window displays all the registered details regarding family composition, farms, fields, land use, products made, implements and structure, utilities, photographs, and others. It should be noted that there is also a map indicating the producer's location to identify their farm. Figure 12 shows an example of the map indicating the location of a producer.

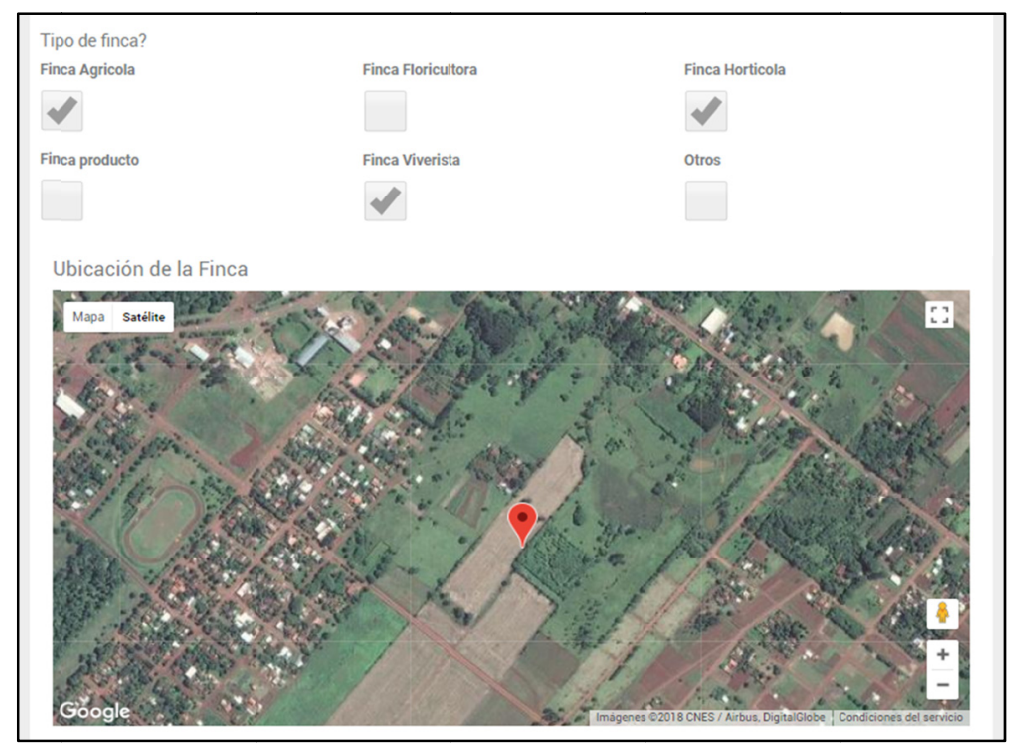

Figure 12. Farm Information

Since a producer may have more than one field and/or farms, all of them are overall displayed on a map, indicating the plot name, number and area in hectares. Figure 13 shows the parcels information. 


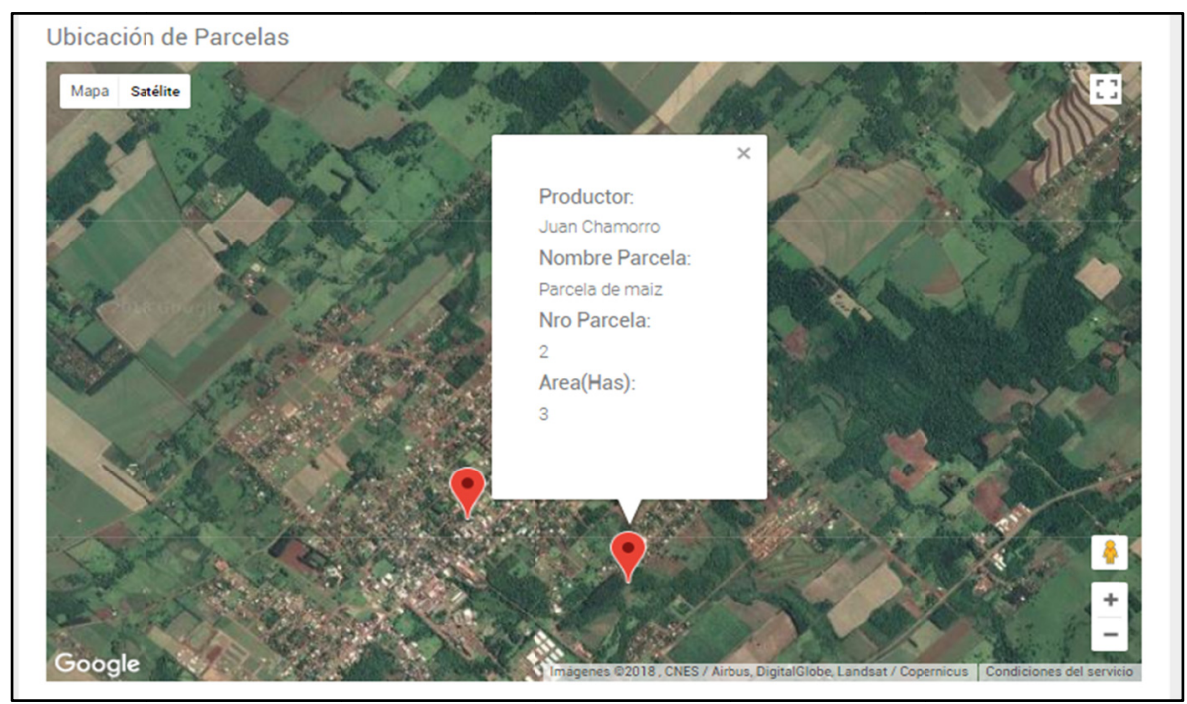

Figure 13. Parcels view

Images registered by users through the Android application can also be viewed, since they are also sent to the server and displayed on the web system. They appear with the capture date, a name and a comment on the image, as shown in Figure 14.

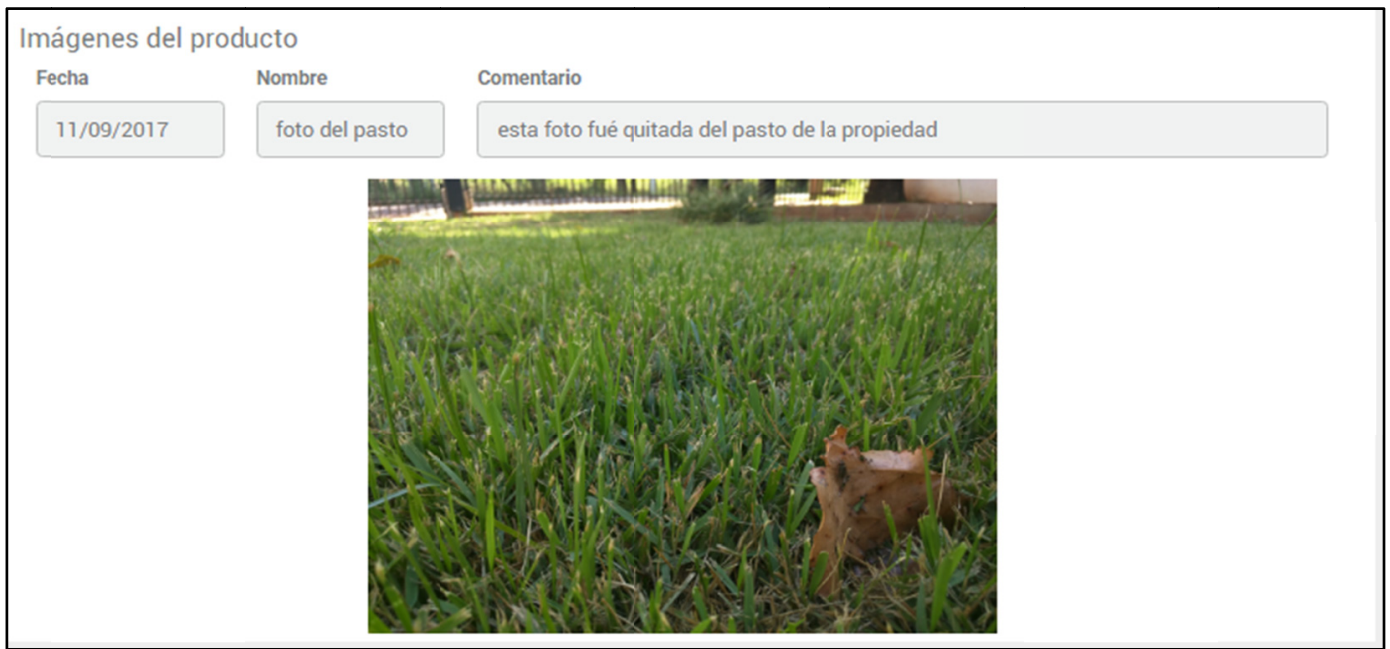

Figure 14. Images view

Therefore, the system developed can significantly help in the management of activities related to family farming, since it surveys all the data of the Family Farmers belonging to the Itapúa Department in Paraguay. Thus, it facilitates the analysis of the information obtained according to variables criteria appropriate for every possible management need.

It should also be noted that by registering through the application, all information will be stored in a centralized database, which, for security reasons, will back up information on a daily basis, ensuring that all the work done can 1 be continued as data will not be lost. Previously, the data collection was done on paper using the RENAF form. However, over the years, with the need for information-based decision-making this method seems to work better.

\section{Conclusions}

Paraguay is a country rich in natural resources. Its tropical climate is excellent for the development of agricultural and livestock activities. However, it is well known that the country uses less technology for farming development. Thus, C7 SustenLAF Application was planned, developed and analyzed considering all the 
benefits it can offer to the government entities of the Itapúa Department, and it is considered a model of technology use to be implemented also in other areas and/or activities carried out in the state and also throughout the country. The application and the Web System are fully scalable and have growing prospects regarding their functions, which means that new routines can be incorporated, if necessary, offering new functionality to cover all government requirements.

The application will be launched with the main goal of enabling the digitization of information, georeferencing of farms, easy and fast access to information, as well as assisting the government management personnel in the decision-making process. Therefore, the use of these systems will facilitate the management of several different activities carried out in family farming, assist administrative processes and allow a full control of activities developed by producers and technicians. Thus, by using the system, it will be possible to detect zones of influence of different types of production, allowing to carry out market research for effective marketing of the products made.

It is also necessary to highlight the importance of creating technology solutions of easy access to facilitate the processing of complex procedures, leading to almost instantaneous results. Thus, the application developed for the Android Operating System promotes the use of free technologies and tools, which leads to money-saving on high-price devices.

\section{References}

CAN (Censo Agropecuario Nacional). (2009). Censo Agropecuario Nacional 2008. Ministerio de Agricultura y Ganadería, Dirección de Censos y Estadísticas Agropecuarias, San Lorenzo, Paraguay. Retrieved from http://www.mag.gov.py/Censo/ Book\%201.pdf

Laudon, K. C., \& Laudon, J. P. (1999). Sistemas de Informação com Internet (4th ed.). Rio de Janeiro: LTC.

Salcedo, S., \& Guzmán, L. (2014). Agricultura familiar en América Latina y el Caribe: Recomendaciones de política (p. 497). Santiago: FAO.

Turban, E., McLean, E., \& Wetherbe, J. (2004). Tecnologia da informação para gestão (3rd ed.). Porto Alegre: Bookman.

Villalba, E. O. H. (2017). Diagnóstico de la fertilidad de los suelos de la agricultura familiar paraguayaRegión Oriental (p. 196). Asunción, Paraguay.

\section{Copyrights}

Copyright for this article is retained by the author(s), with first publication rights granted to the journal.

This is an open-access article distributed under the terms and conditions of the Creative Commons Attribution license (http://creativecommons.org/licenses/by/4.0/). 